\title{
Corruption and Productivity: Firm-level Evidence
}

\author{
Donato De Rosa* \\ The World Bank, Washington DC, USA \\ Nishaal Gooroochurn \\ London Metropolitan University, UK \\ Holger Görg \\ Kiel Institute for the World Economy and University of Kiel, Germany; IZA \\ JEL O14; P37 \\ Corruption; productivity; Central and Eastern Europe; CIS.
}

\begin{abstract}
Summary
Using enterprise data for the economies of Central and Eastern Europe and the CIS, this study examines the effects of corruption on productivity. Corruption is narrowly defined as the occurrence of informal payments to government officials to ease the day-to-day operation of firms. The effects of this "bribe tax" on productivity are compared to the consequences of red tape, which may be understood as imposing a "time tax" on firms. When testing effects in the full sample, only the bribe tax appears to have a negative impact on firm-level productivity, while the effect of the time tax is insignificant. We also find that the surrounding environment influences the way in which firm behaviour affects firm performance. In particular, in countries where corruption is more prevalent and the legal framework is weaker, bribery is more harmful for firm-level productivity.
\end{abstract}

\section{Introduction}

One of the most obvious facts about corruption is that poor countries tend to be the most corrupt (e.g., Bardhan 1997). Available data at the country level support this view. For instance, there is a 0.81 correlation between GDP per capita and Transparency International's Corruption Perception Index, one of the most commonly used measures of corruption. Beyond this simple observation, however, understanding corruption is not an easy task. For instance, it is debatable whether corruption is a cause of low incomes per capita, one of its consequences or, as it seems more likely, whether the relationship between corruption and income is an intricate one, made of a web of dynamic interactions, whereby some countries appear trapped in a condition of low incomes and high corruption. ${ }^{1}$

\footnotetext{
* The authors are grateful to Irena Grosfeld, Erich Gundlach, Mariana Iootty, Johann Graf Lambsdorff, Jorge Pena, Ekaterina Zhuravskaya, seminar participants at the Kiel Institute and the World Bank, and two anonymous referees for many helpful comments.

1 There is an extensive literature on the causes of corruption, see, for example, Acemoglu et al. (2001) who focus on the role of inherited institutions, La Porta et al. (1999) who look at the importance of legal origin, or Brunetti and Weder (2001) who investigate the role of a free press.
} 
In common parlance and in academic research corruption is defined in various ways. Most often it is understood as bribery, whereby an official demands informal payments to perform an official task - e.g. issuing a license - or to circumvent laws and regulations. State capture may also qualify for the definition of corruption, when bureaucrats subject themselves to more or less legal forms of lobbying, involving monetary bribes or other forms of exchange of favours, to afford preferential treatment to certain private interests. Political patronage, nepotism and cronyism, whether or not they involve monetary kickbacks, may also be included in a broad definition of corruption.

For our purposes, corruption is defined as a "bribe tax", a certain amount of money necessary to enforce a contract between an individual and the state. In this asymmetric relationship, the state - or its agents - define the property rights of individuals and enforce them with a monopoly on the legitimate use of force. The institutions that govern this type of "vertical" transactions between the state and its citizens are defined by Acemoglu and Johnson (2005) as property rights institutions and are distinguished from contracting institutions that regulate "horizontal" transactions among ordinary citizens. Property rights institutions are inefficient when they allow those who control the state to extract rents from producers (Acemoglu 2006) and the extortion of bribes from firms may be viewed as a form of rent extraction perpetrated by bureaucrats (Shleifer/Vishny 1998).

The aim of this paper is to investigate the link between corruption and economic performance, more specifically, productivity. Our analysis exploits the advantages of firm level data by using the information contained in the 2009 Business Environment and Enterprise Performance Survey (BEEPS) of firms in 28 countries of Central and Eastern Europe and Central Asia. The sample of countries is very diverse. It covers all the formerly communist countries of Europe and the Former Soviet Union, which have undergone the profound institutional transformation connected with transition to a market economy. The group of formerly communist countries presents substantial variation, ranging from the low income economies of Central Asia, to high income Central European countries, which, as members of the EU, tend to have a fully developed market system.

Unlike similar country level studies using broad definitions of corruption and institutional quality combined with aggregate measures of economic performance (e.g., Lambsdorff 2003; Meon/Sekkat 2005), investigation of the effects of bribery on firm level productivity will allow to be more precise regarding the incentives of economic agents to engage in corrupt behaviour and the consequences this has for productive efficiency. Variables for firm level bribery and productivity can be obtained from the BEEPS database, which, in addition to information on the occurrence of bribing and other aspects of firm operation and performance, allows estimating a measure of total factor productivity (TFP) at the enterprise level.

The need to recur to bribery is often linked to the power of government officials to impose and enforce regulatory requirements on individuals and firms and to exact bribes in the process (see, for example, Djankov et al. 2002). In order to account for this possibility, it is necessary to identify some measure of the power that officials have over firms as enforcers of regulatory requirements. The BEEPS survey offers such a measure at the firm level. It refers to the time that enterprise managers are required to spend complying with government regulations, amounting to a time tax imposed on firms. This may be interpreted as an opportunity cost borne by firms, which, in isolation or in combination with the bribe tax, potentially constitutes a drag on enterprise performance. The availability 
of a firm level measure for the time spent dealing with bureaucracy offers the opportunity to perform a direct test of the so-called "efficient grease" hypothesis, which is explicitly defined in the literature in terms of bribery helping reduce the time required for some interaction between an economic agent and the state (e.g., Lui 1985). ${ }^{2}$

The effects of corruption on productivity are modelled based on a firm level production function. ${ }^{3}$ This paper offers a number of novelties with respect to the existing literature on the consequences of corruption. First, the analysis makes use of cross-country firm level data in order to investigate the effects of country-level characteristics in mitigating the negative productivity impact of bribe payments. Second, we deal with the potential endogeneity of corruption at the firm level using an instrumental variables approach. To do so, we make use of the rich firm level data we have available in the BEEPS data to come up with reasonable instruments. Third, the time spent dealing with bureaucracy, which is intimately linked to bribe payments, is directly examined.

Results of the econometric analysis highlight some differences between the effects of bribery and the time tax. Across the entire sample, whereas the time devoted to complying with government regulations has no significant effect on firm level productivity, corruption has a statistically significant negative effect in instrumental variable specifications. Additionally, regression results show no evidence in favour of the "efficient grease" hypothesis, whereby bribing would be a second best option to achieve higher productivity levels by helping firms circumvent burdensome regulatory requirements. Namely, when bribing is made conditional on the time spent dealing with government regulations, the interaction term has no significant effect on productivity, implying that no trade-off emerges between the time and the bribe tax.

We test the hypothesis that the effects of corrupt behaviour on firm performance vary depending on broader country characteristics. In order to do so, bribery experienced by individual firms is made conditional on broader country characteristics that may play a role in influencing individual choices to engage in corrupt behaviour. The first measure used is the Transparency International Corruption Perception Index (CPI), which provides an independent measurement of perceived corruption in 180 countries, based on 13 different expert and business surveys. Inclusion of country-wide corruption may be interpreted to reflect the extent to which peer effects may be conducive to corrupt behaviour, as in theoretical models that explain the persistence of corruption with social effects, such as Tirole (1996). The second country-wide measure is the World Economic Forum (WEF) index of the effectiveness of the legal framework in resolving disputes,

2 Use of the time tax as a specific outcome of the institutional inefficiencies linked with corruption distinguishes our paper from other studies, such as Méon and Sekkat (2005) and Méon and Weill (2010). These authors, for lack of more precise country level data explicitly reflecting the time involved in interactions with the state, use generic country level proxies of "governance" to test whether corruption does indeed act as efficient grease.

3 Using the same BEEPS sample, Blagojevic and Damijan (2013) differentiate the effect of corruption by firm ownership. Fisman and Svensson (2007) look at the relationship between corruption and firm growth using firm level data for Uganda. Our paper is different in a number of aspects. First, we use firm level data for a number of countries in Central and Eastern Europe and Central Asia, which allows us to explore cross country heterogeneity. This is important, as we show, since we find strong differences in the relationship between corruption and productivity in different countries. Second, we look at productivity, not growth of sales as in Fisman and Svensson (2007). 
intended to capture the possibility that a higher likelihood of sanctioning by the legal system may act as a deterrent. ${ }^{4}$

Regression analysis shows that firms that do not pay bribes in environments with a high prevalence of corruption and inefficient legal frameworks experience higher productivity. Furthermore, when overall levels of corruption exceed a certain threshold, the total effect of corruption on productivity - i.e. the combination of individual and country effects is increasingly negative. This indicates that, whereas environmental circumstances are beyond the choice set of individual firms, managers still have some degree of autonomy in deciding whether to recur to bribery or not and this affects firm level productivity.

The remainder of the study is structured as follows. The following section provides an overview of the relevant literature on the possible effects of corruption on economic performance. Next is a description of the BEEPS 2009 data, as well as an exposition of the econometric methodology. The fourth section demonstrates the effects of corruption on productivity, both unconditional and conditional on the time tax experienced by individual firms and on country characteristics in terms of prevalence of corruption and efficiency of the legal framework. The final section concludes.

\section{Background literature}

Corruption is sometimes seen a second-best option when it helps reduce the time involved in dealing with burdensome regulatory requirements. According to the proponents of this "efficient grease" hypothesis this would happen since, in spite of the transaction costs it entails, bribery would lead to lower effective red tape for the firm, hence increasing firm performance and productivity.

A theoretical framework for this efficiency enhancing role of corruption is provided by Lui's (1985) queuing model, where the size of bribes by different economic agents reflects their different opportunity cost, with more efficient agents more able or willing to buy lower effective red tape, reflected in a lower "time tax". As a consequence, a license or contract awarded on the basis of bribe size could achieve Pareto-optimal allocation. However, Kaufmann and Wei (1999) identify a major shortcoming in Lui's (1985) assumptions, namely that the regulatory burden is treated as exogenous, independent of the incentives for officials to take bribes. This may not be the case since the incentives of bureaucrats can be modified by specific policy measures. Ultimately, because of this assumption, Lui's theory is partial equilibrium in nature, and may not hold in a general equilibrium.

More generally, Bardhan (1997) argues that red tape and corruption are not exogenous, as they are caused - or at least preserved or aggravated - by those who benefit from an overregulated and corrupt system. Hence, as argued by Aidt and Dutta (2008), even if corruption helps overcome cumbersome regulation in the short term, it creates incentives to create more such regulation in the long term. Empirical evidence, especially at the micro level, is generally not supportive of the efficient grease hypothesis ${ }^{5}$, with corruption found

4 North (1990) distinguishes between "informal norms," "formal rules" and "enforcement" as pillars of the institutional framework of an economy. For our purposes, the CPI might also be viewed as a proxy of informal norms of behaviour dictated by social networks, while the WEF index of the efficiency of the legal framework might be interpreted as a proxy for the quality of formal rules or their enforcement.

5 One of few exceptions is Egger and Winner (2005) who, based on country-level evidence, argue that corruption can help overcome regulatory obstacles and stimulate FDI. 
to increase the time spent by managers dealing with red tape (Kaufmann/Wei 1999) and to hamper firm growth (Fisman/Svensson 2007). ${ }^{6}$

If corruption were a means to "greasing the wheels of commerce" it could possibly have positive effects on economic performance by reducing transaction costs in the vertical transactions between the state and its citizens. However, the theoretical and empirical evidence in favour of the opposite argument appears more convincing, highlighting the negative consequences of corruption for resource allocation, entrepreneurship, investment and innovation.?

The main argument is that the prevalence of corruption may distort resource allocation by increasing the returns to rent-seeking compared to those of productive activities (Baumol 1990). An extremely corrupt environment may induce individuals to minimize interaction with the state by expanding more slowly, operating in the informal sector or even forgoing entrepreneurial activity altogether. Corroborating this point, Djankov et al. (2002) find that entry of new firms is more difficult in the presence of greater corruption and larger unofficial economies.

Corruption also affects the allocation of entrepreneurial talent, when, in highly corrupt environments, entrepreneurs may devote greater efforts to obtaining valuable licenses and preferential market access than to improving productivity (Murphy et al. 1991). When entrepreneurial talent is directed towards productive activity, the rate of innovation and investment is likely to increase with positive consequences for productivity and income growth. In contrast, when talent is directed towards rent extraction, returns to talent are maximized by appropriating wealth rather than wealth creation (Murphy et al. 1991, 1993; Acemoglu/Verdier 1998).

The sources of productivity enhancements, technological progress and investment, may be directly affected in corrupt environments. For instance, entrepreneurs may have incentives to adopt inefficient "fly-by-night" technologies of production with an inefficiently high degree of reversibility, which allows them to react more flexibly to future demands from corrupt officials - and more credibly threaten to shut down operations (Svensson 2003). Additionally, vested interests may directly oppose the adoption of new technologies, which would threaten their position of influence by rendering obsolete the older technological vintages they control (Krusell/Rios-Rull 1996). Finally, corruption may erect de facto entry barriers into otherwise competitive markets with discouraging effects for investment decisions, in a mechanism similar to the one proposed by Alesina et al. (2005). Alternatively, the monetary cost involved in the payment of bribes may simply limit the amount of resources available to expand productive capacity via investment.

In addition to distortionary allocation effects, the discretionary power of state officials will increase the risk of expropriation thus reducing the appropriability of returns to investment and innovation (Demsetz 1967 and Alchian/Demsetz 1973). This will further diminish rewards for entrepreneurial behaviour, while propping up inefficient firms engaged in corrupt practices. In this spirit, Johnson et al. (2002), using firm-level data from former communist countries in Europe, find a negative effect of paying bribes on investment and interpret this finding as the effect of insecure property rights.

\footnotetext{
${ }^{6}$ Hellman et al. (2000) also find a negative correlation between bribe payments and sales, although these authors do not instrument for bribe payments.

7 For an overview of the consequences of corruption, see Lambsdorff (2003), Svensonn (2005), and Shleifer and Vishny (1998).
} 
Whereas corruption can impact economic performance through all these channels, its adverse effects may be non-linear and depend on the overall level of institutional quality (or governance) in the country. Two studies - both based on country level data - find such non-linearities in the relationship between corruption and growth, namely a more negative effect when institutional quality is poor. Méon and Sekkat (2005), based on a sample of 71 countries between 1970 and 1998 and using various proxies for both corruption and governance, ${ }^{8}$ find that corruption is most harmful to growth where governance is weak. Méndez and Sepúlveda (2006) examine country-level evidence by using different proxies for corruption ${ }^{9}$, as well as the Freedom House index of political freedom as a proxy for overall institutional quality. They find that the relationship between corruption and growth is non-monotonic with corruption having negative effects only at high levels of incidence.

\section{Data and methodology}

To assess the effects of corruption on firm performance this paper uses the 2009 EBRD/World Bank Business Environment and Enterprise Performance Survey (BEEPS) of firms in 28 transition and developed countries. ${ }^{10}$ The BEEPS was specifically conceived to assess the extent to which government policies and practices facilitate or impede business activity. It therefore provides a vast array of information on the behaviour and performance of firms, which allows to explicitly model the possible influence of various firm characteristics on the occurrence and impact of corruption at the firm level. The main disadvantage of the data is that it is only available for a cross section in 2009, which means we cannot look at changes in firm performance over time. Also, it makes interpretation of the estimated effects as "causal" more difficult, hence we revert to an instrumental variables approach in the analysis below.

Table 1 lists the countries included in the sample. It shows that there is substantial variation in terms of income group (based on the World Bank classification for 2008) ${ }^{11}$ and EU membership. Such high dispersion in income per capita provides a particularly rich sample, that allows controlling for specific country characteristics linked to the level of development and, in particular, to the quality of the institutional environment. The business environment is examined by asking firms to assess how various factors affect business operations, including infrastructure, financial services, government regulation, tax administration, judiciary functions. Corruption is also examined, allowing us to model

8 The authors use the Transparency International CPI, as well as a number of indicators from the World Bank Governance Indicators, as proxies for corruption and governance.

9 The authors use the International Country Risk Guide (ICRG), the IMD index of corruption is published by the Institute for Management Development (IMD) and the corruption perceptions index (CPI) compiled by Transparency International.

10 The data set and documentation is available at http://www.ebrd.com/pages/research/economics/ data/beeps.shtml. Previous rounds of the BEEPS surveys were carried out in 1999, 2002 and 2005. Unfortunately, given the changes in survey design, a meaningful link between the 2009 and earlier versions is not feasible. Also, the survey nature of the data leads to the loss of many observations in multivariate regressions, owing to non-response rates.

${ }^{11}$ Economies are divided according to 2008 GNI per capita. The groups are: low income, $\$ 975$ or less; lower middle income, $\$ 976-\$ 3,855$; upper middle income, $\$ 3,856-\$ 11,905$; and high income, $\$ 11,906$ or more. See http://web.worldbank.org/WBSITE/EXTERNAL/ DATASTATISTICS/0,,contentMDK:20420458 menuPK:64133156 pagePK:64133150 piPK:64133175 theSitePK:239419,00.html (accessed 15 October 2009). 
Table 1 List of countries in the sample

\begin{tabular}{|c|c|c|}
\hline Economy & Income group & EU member \\
\hline Croatia & High income & \\
\hline Estonia & High income & $\checkmark$ \\
\hline Slovenia & High income & $\checkmark$ \\
\hline Czech Republic & High income & $\checkmark$ \\
\hline Hungary & High income & $\checkmark$ \\
\hline Slovak Republic & High income & $\checkmark$ \\
\hline Belarus & Upper middle income & \\
\hline Bosnia and Herzegovina & Upper middle income & \\
\hline Bulgaria & Upper middle income & $\checkmark$ \\
\hline Kazakhstan & Upper middle income & \\
\hline Latvia & Upper middle income & $\checkmark$ \\
\hline Lithuania & Upper middle income & $\checkmark$ \\
\hline Macedonia, FYR & Upper middle income & \\
\hline Montenegro & Upper middle income & \\
\hline Poland & Upper middle income & $\checkmark$ \\
\hline Romania & Upper middle income & $\checkmark$ \\
\hline Russian Federation & Upper middle income & \\
\hline Serbia & Upper middle income & \\
\hline Turkey & Upper middle income & \\
\hline Albania & Lower middle income & \\
\hline Armenia & Lower middle income & \\
\hline Azerbaijan & Lower middle income & \\
\hline Georgia & Lower middle income & \\
\hline Moldova & Lower middle income & \\
\hline Ukraine & Lower middle income & \\
\hline Kyrgyz Republic & Low income & \\
\hline Tajikistan & Low income & \\
\hline Uzbekistan & Low income & \\
\hline
\end{tabular}

Source: World Bank

its occurrence and impact on the operation and performance of firms. A list of variables used and their description is given in Table A1, and their descriptive statistics are in given in Table A2 in the appendix.

A typical concern when using survey data is that of individual perception bias (Kaufman/Wei 1999). Some firms may, for instance, consistently provide positive or negative answers depending on their overall perception of the business climate. In principle, assuming that the bias is uncorrelated across groups of respondents, individual perception bias contributes only to the standard error of estimates obtained from the survey responses. In cross-country surveys, such as the BEEPS, the group within which the bias is likely to be correlated is the particular country in which respondents operate. Perception bias at the country level could originate from different cultural norms and degrees of political freedom across countries, which may influence the choice of specific ratings and the will- 
ingness of business people to criticise state institutions. Fries et al. (2003) check for such perception bias in the BEEPS 2002 by statistically comparing measures obtained from the aggregation of survey responses to related objective measures and find no significant perception biases across the countries in the sample. Since the BEEPS 2009 follows a similar methodology, we may be reasonably confident that perception bias will not affect the results of the analysis. However, as a further control, the analysis that follows will make use of sector and country level fixed effects.

\subsection{The bribe tax and productivity}

The aim of this study is to evaluate the extent to which corrupt practices by firms may be a drag on their productivity or lead to productivity improvements. In order to capture the complexity of the phenomenon of corruption and its potentially varied effects on the performance of individual firms, the empirical methodology will proceed in three steps. First, is an analysis of the effects of the bribe tax and of the time tax on individual firms, controlling for firm, sector and country characteristics that may influence both phenomena. Second, we proceed with an explicit test of the "efficient grease" hypothesis. Possible trade-offs between time consuming compliance with government regulation and the payment of bribes are modelled by including an interaction term between the time and the bribe tax and observing its effects on firm level productivity. Finally, the effect of individual corrupt conduct on firm level productivity is made conditional on the level of institutional quality in the country. That is, in addition to country fixed effects, the econometric specification includes an interaction term between the firm level bribe tax and independent assessments of the prevalence of corruption or the quality of the legal framework in the country.

We model the effect of corruption on TFP using an augmented production function, including, in addition to factor inputs, the set of firm, industry and country characteristics that are assumed to have an effect on output. Hence, we include corruption explicitly in the determination of output, as in (1):

$$
\begin{aligned}
y_{i j c}= & \alpha_{1} K_{i j c}^{\text {land }}+\alpha_{2} K_{i j c}^{\text {equipment }}+\alpha_{3} L_{i j c}+\alpha_{4} M_{i j c}+ \\
& +\beta \text { corruption }_{i j c}+\gamma X_{i j c}+d_{j}+d_{c}+\varepsilon_{i j c}
\end{aligned}
$$

where $y_{i j c}$ is $\log$ output by firm $i$ in industry $j$ and country $c$ and $K^{\text {land }}, K^{\text {equipment }}, L$ and $M$ are $\log$ of land, machinery, employment and materials, respectively. ${ }^{12}$

12 The estimation of a one-step augmented production function to investigate the determinants of TFP is common in the literature, see, for example, Javorcik (2004). An alternative is a two step approach. A first step would be to estimate a simple production function only including $K^{\text {land }}$, $K^{\text {equipment }}, L$ and $M$, and save the estimated residual as TFP. In a second step, TFP is then modelled as being determined by a number of firm and industry characteristics. The one step approach is more efficient than the two step approach. However, the latter has the advantage that it allows to take care of country level heterogeneity in productivity by estimating the first step production function separately for each country. We also employ the two step approach as a robustness check in the working paper version (De Rosa et al. 2010), results are similar to those reported below. Estimation of TFP at the firm level is, of course, a task fraught with methodological difficulties. Prime among these is the simultaneity problem in the estimation of factor inputs, which are likely to be endogenously determined with output (see, for example, Levinsohn/Petrin 2003). However, due to the cross section nature of our data we are not able to implement an approach a la Levinsohn and Petrin. This should be borne in mind in the interpretation of our empirical results. 
The main variable of interest is corruption $_{i j c}$, which is the measure of corruption at the firm level. It is defined as a "bribe tax", in the form of a dummy equal to one if a firm replies "frequently", "usually" or "always" to the question "is it common to have to pay some irregular additional payment or gifts to get things done with regard to customs, taxes, licenses, regulations, services, etc." ${ }^{13}$ The same specification can be used to test the direct effects of the "time tax", defined as the percentage of senior management time devoted to dealing with bureaucratic requirements, by including it in the model as a substitute for the "bribe tax". Consideration of both variables allows verifying the extent to which the time and the bribe tax are different phenomena, with different implications for firm productivity. It should be noted that the overall effect of bribes on productivity might be underestimated due to selection bias, as firms that had to pay the largest bribes may have been driven out of business altogether and, therefore, they are not in the dataset.

$\mathrm{X}_{\mathrm{ijc}}$ is a vector of control variables that serve to detect observable aspects of firm heterogeneity in our data to allow identification of the effect of the bribe tax on productivity. It consists of sizeM, sizeL, age, exporter, innovator and foreign-owned. SizeM and sizeL are dummy variables representing medium and large firms, respectively. Larger firms are expected to have higher productivity due to the effects of scale economies. The variable age represents the age of firms in 2008, capturing effects such as the vintage of the firm or learning by doing externalities on TFP.

Innovator, exporter, and foreign-owned are all dummy variables indicating whether the firm is engaged in innovation (in terms of having positive R\&D expenditure), involved in exports and owned by foreign investors. These variables are expected to have a positive effect on productivity. In particular, innovation and R\&D expenditures tend to positively affect firm productivity since they lead to the development of more efficient production technologies or to the more effective adoption of technologies developed outside the firm (Aw et al. 2008; Klette/Kortum 2004). At the same time, exporting activity has been found in several empirical studies to be positively associated with firm-level productivity (Wagner 2007). Foreign ownership is associated with various measures of firm performance, including investment, innovation and productivity, since foreign owners can be expected to transfer technology and know-how to domestic affiliates (see, for example, Girma/Görg 2007).

In order to account for the possibility that increased competition may act as a form of control on corruption, while, at the same time, affecting firm level productivity, $\mathbf{X}_{\mathbf{i j c}}$ also includes a variable for the perceived intensity of competition. The variable is defined "How much of an obstacle are competitors to your operations?". Specifically, firms are asked to rank whether competition is an obstacle on a scale from 0 (no obstacle) to 4 (very severe obstacle). We define our variable as the difference between the individual firm's response and the country average. As mentioned earlier, the rationale for including the competition variable is that, as firms' profits are driven down by competitive pressure, there are no excess profits from which to pay bribes (Ades/Di Tella 1999).

\footnotetext{
13 The BEEPS also includes questions that ask more specifically about the level of bribery, i.e., the amount that is typically paid by a firm to "get things done". Perhaps unsurprisingly, this very delicate question is only answered very rarely by firms. For example, for the regression in Table 3 , column 1 (for which we have 1,666 observations when using the dummy) we would only have 275 observations if we defined bribery using the responses to the question about the amount of money spent. Hence, we prefer the dummy variable for our analysis.
} 
$\mathrm{X}_{\mathrm{ijc}}$ also includes two measures of the firm's perception of the quality of the institutional environment. The first is a dummy variable equal to one if the firm responds that the quality of courts is a major or very severe obstacle to operating a business. The second is a dummy variable that is similarly defined if a firm sees political instability as a severe problem. Including these two measures allows us to capture some aspects of institutional quality that may be correlated with corruption and, if not controlled for, may therefore bias our results.

Finally, $d_{j}$ and $d_{c}$ include a full set of industry and country dummies, respectively, and uijc is the idiosyncratic error term, which allows for clustering at the country-industry level.

\subsection{Efficient grease: trade-offs between the bribe tax and the time tax}

The model in equation (1) can be expanded to investigate the extent to which bribes may be a second best outcome in a context where inefficient bureaucracy leads to a time tax for producers. In other words, when regulation is overly restrictive, corruption may aid entrepreneurs in their interaction with the state, thus leading to a beneficial impact on productivity. A direct way to test this hypothesis would be to include the bribe tax and the time tax jointly in the empirical specification, together with their interaction. The latter would test the extent to which the effect of bribes on productivity is conditional on time consuming dealings with bureaucracy; in other words, it would allow a direct test of the efficient grease hypothesis, as in equation (2):

$$
\begin{aligned}
y_{i j c}= & \alpha_{1} K_{i j c}^{\text {land }}+\alpha_{2} K_{i j c}^{\text {equipment }}+\alpha_{3} L_{i j c}+\alpha_{4} M_{i j c}+\beta_{1} \text { corruption }_{i j c}+\beta_{2} \text { timetax }_{i j c}+ \\
& +\beta_{3}\left(\text { corruption }_{i j c} * \text { timetax }_{i j c}\right)+\gamma X_{i j c}+d_{j}+d_{c}+\varepsilon_{i j c}
\end{aligned}
$$

A significant coefficient for $\beta_{3}$ will indicate that the effect of corruption on productivity depends on the degree to which the firm is engaged in time consuming relations with the state. In particular, a positive coefficient for $\beta_{3}$ would indicate that a high time tax is accompanied with less negative - or even positive - effects of corruption on productivity, thus providing evidence in favour of "efficient grease", with corruption helping to mitigate the effects of burdensome regulation. The same result could also be consistent with a setting where bribe-revenue maximizing bureaucrats may use red tape (the time tax) as a screening device to give production licenses to high-productivity firms (Banerjee 1997). In such a model, every firm pays the same amount of bribes while high productivity firms spend more time with bureaucrats.

\subsection{Institutional quality: interaction between firm-level and country-level effects}

As a further step in our analysis, in order to check whether the effect of corruption on firm level productivity differs depending on country characteristics, we extend equation (1) and interact corruption with country level measures of institutional quality that may be hypothesized to be relevant in determining individual incentives for corrupt behaviour. For this we use two alternative indicators. First is the Transparency International Corruption Perception Index (CPI) for the year 2008, which allows investigating whether the prevalence of corruption at the country level has implications for firm behaviour and, consequently, productivity performance. The CPI captures the perceived levels of publicsector corruption in a given country and is a composite index, drawing on different expert 
and business surveys. It may be interpreted to reflect the possibility of social effects as described earlier, whereby in a more corrupt environment individual entrepreneurs would have stronger incentives to behave corruptly. The CPI ranges from zero (highly corrupt) to ten (highly clean). It varies across countries and is fixed across sectors for a given country.

As can be seen in Table 2, the average levels of productivity, bribe tax and CPI are different between low CPI and high CPI countries ${ }^{14}$. These variations could imply that the impact of bribe tax on productivity could be different for high and low CPI countries. No major differences can be depicted in the level of time tax, however. ${ }^{15}$

Table 2 Summary statistics by group of countries

\begin{tabular}{lrrrrrrrrrrr}
\hline & \multicolumn{2}{c}{ Total } & \multicolumn{2}{c}{ Non EU } & \multicolumn{2}{c}{ EU } & \multicolumn{2}{c}{ CPI $<\overline{\text { CPI }}$} & \multicolumn{2}{c}{ CPI $>\overline{\text { CPI }}$} \\
\cline { 2 - 12 } & Mean & Std. Dev. & Mean & Std. Dev. & Mean & Std. Dev & Mean & Std. Dev. & Mean & Std. Dev. \\
\hline TFP & 0.148 & 0.916 & 0.150 & 0.941 & 0.144 & 0.874 & 0.239 & 0.983 & 0.090 & 0.867 \\
Bribe Tax & 0.099 & 0.298 & 0.139 & 0.346 & 0.030 & 0.171 & 0.195 & 0.396 & 0.030 & 0.169 \\
Time Tax & 14.528 & 18.223 & 14.313 & 19.819 & 14.884 & 15.220 & 14.669 & 21.172 & 14.430 & 15.851 \\
CPI & 3.393 & 1.150 & 2.863 & 0.904 & 4.288 & 0.949 & 2.287 & 0.362 & 4.191 & 0.814 \\
\hline
\end{tabular}

Note: TFP is calculated as a residual from a simple production function, $y_{i j c}=\alpha_{1} K_{i j c}^{\text {land }}+\alpha_{2} K_{i j c}^{\text {equipment }}+\alpha_{3} L_{i j c}+$ $\alpha_{4} M_{i j c}+e_{i j c}$

As a robustness check, we also use an alternative measure of institutional quality, namely the World Economic Forum's index of the effectiveness of the legal framework is solving legal disputes, which can be interpreted as a proxy for the ability of formal institutions to enforce contracts and prevent or sanction the occurrence of corrupt practices. This is also a country level index for the year 2008, where increases in the index imply better legal quality.

Including either of the indices in the model gives the following equation (3) as

$$
\begin{aligned}
y_{i j c}= & \alpha_{1} K_{i j c}^{\text {land }}+\alpha_{2} K_{i j c}^{\text {equipment }}+\alpha_{3} L_{i j c}+\alpha_{4} M_{i j c}+ \\
& +\beta \text { corruption }_{i j c}+\lambda\left(\text { corruption }_{i j c} * \text { institution }_{c}\right)+\text { sinstitution }_{c}+ \\
& +\gamma X_{i j c}+d_{j}+d_{c}+\varepsilon_{i j c}
\end{aligned}
$$

In equation (3) a significant coefficient for $\lambda$ will indicate that the effect of corruption on productivity depends on the country's level of institutional quality, as represented by the diffusion of corruption and the efficiency of the legal system. In particular, a positive (negative) coefficient of $\lambda$ will indicate that high institutional quality will lessen (strengthen) the negative effect of corruption at the firm level on productivity.

${ }^{14}$ Low and high CPI countries are defined as countries with CPI below and above the mean level, respectively.

15 The use of perceived corruption (the CPI index by Transparency International) may be problematic if there are discrepancies between perceived and actual corruption. Olken (2009) shows that this may be the case by examining a specific case of a road building project in rural Indonesia. $\mathrm{He}$ compares corruption perceived by villagers with a more objective measure of corruption based on missing expenditure. While a difference between actual and perceived corruption may potentially be a problem, one should keep in mind that Transparency International reports broad country level indices which are based on expert and business surveys. 


\section{Econometric analysis}

We now turn to the results of the econometric analysis in the three stages outlined above. Namely, we examine the effects of corruption on productivity; of the interaction between corruption and the time tax; and of the relevance of country characteristics for firm level outcomes.

As discussed, the determinants of productivity are estimated using a one-step augmented production function. In order to address the potential endogeneity of firm level bribe tax and time tax, equation (1) is estimated with an instrumental variable (IV) approach. Implementation of the IV method requires adequate instruments that fulfil two conditions, namely being correlated with the endogenous variable and being uncorrelated with the error term in equation (1).

While it is difficult to find fully excludable instruments, the BEEPS data set offers a number of potential candidates. For instance, firms are asked whether or not the owner is female. This is likely to be correlated with corruption, as there is evidence that women are less likely to engage in or condone corruption (e.g., Swamy et al. 2001). It is also established in the literature that women are more risk averse than men (Barsky et al. 1997), which may be one explanation for why they are less likely to engage in corrupt behaviour, which can be seen as a risky activity. It is not a priori obvious, however, that gender should have a direct influence on productivity that is not related to the indirect channel of risk aversion. Also, the data relate to the owner of the firm, not the manager. While the owner may have more influence on fundamental decision such as whether or not a firm should engage in illegal activities such as corruption, the owner may matter less for operational decisions that affect productivity. Hence, we would argue that this may be a relevant and valid instrument for corruption.

An alternative instrumental variables candidate is a firm's reply to a question as to whether they submitted an application for an electricity connection over the last two years. This allows us to generate a dummy variable equal to 1 if the firm did not submit an application and 0 if it did. This variable is arguably likely to be correlated with corruption, since it would imply interaction with public officials who have to grant the firm its right to be connected with the electricity grid. This would, hence, be a good opportunity for corrupt officials to demand a payment, either in cash or in terms of time. On the other hand, a dummy whether or not a firm submitted an application for electricity is unlikely to be correlated with productivity. Since one may assume that a firm needs some access to electricity to start operating, it appears reasonable that the application that is mentioned in the survey must relate to an additional or new connection. There is therefore no a priori reason why, conditional on the covariates in equation (1), there should be a correlation between the incidence of the application and TFP. It is also important to point out that this variable relates to the incidence of the application, not the actual connection to electricity. While this may of course lead to a new connection in the future, which may then possibly (but not necessarily) lead to an increase in productivity, this is unlikely to be the case in the current period.

Furthermore, we employ two additional instruments. These are the country-industry averages of bribe tax and time tax. These instruments are also employed by Fisman and Svensson (2007). Firms' experiences and perceptions of corrupt practices or of the burden in terms of time associated with red tape are likely to be influenced by the experiences of other competitors in the same industry. Hence, we would expect our additional instruments to be correlated with the firm-level bribe tax and time tax variables. The necessary 
assumption for the validity of the instruments is that there is no direct effect of the sectoral average on a firm's level of productivity conditional on the included covariates. This would not be the case if there were processes at the industry level that affect firm level productivity and bribes. An example may be governments favouring sectors that are particularly productive (or unproductive) in their attitude towards corruption. As in Fisman and Svensson (2007), we are not aware of any systematic evidence to support this claim. Hence, we are cautiously confident that our instrument does not just pick up any unobserved industry effects that are correlated with firm level productivity.

We based our selection of instruments on initial tests for the validity of overidentification restrictions and relevance of the instruments using standard tests. These tests are in line with the assumption that the dummy whether the owner is female and the industry average are valid instruments in all cases. The dummy capturing whether a firm applied for an electricity connection only appears valid and relevant in the case of the bribe tax, hence, we only use it when looking at the effects of bribes on productivity. It is important to point out, however, that we cannot conclusively test for the validity of instruments. This should be kept in mind in the interpretation of results.

The results reported in Table 3 are, hence, based on using a female dummy, electrical connection application dummy, and industry level bribes, as instruments for bribe tax. For time tax, we do not use the electrical connection dummy, only the female dummy and industry level time tax as instruments. We report tests for the relevance of the instruments in these specifications, using a joint $\mathrm{F}$ test to verify whether the instrument candidates are correlated with the endogenous variable in Table 3. The F-statistics are higher than 20 in both cases confirming that the instruments are jointly highly correlated with the respective firm level corruption variable. Furthermore, we provide a Hansen-Sargan J test of overidentification restrictions to check that the IV candidates are uncorrelated with the error term in equation (1). The p-values of the Hansen-Sargan test confirm the validity of the chosen IV, as we cannot reject the null of instrument validity.

The second stage results of the effects of time and bribe taxes on productivity according to the baseline estimation of equation (1) are presented in Table 3. Columns (1) and (2) present the results using an OLS estimator, while columns (3) and (4) show IV estimates. ${ }^{16}$ Note firstly that the coefficient on the production factors capital, labour, land and materials are all positive as expected. Furthermore, exporters and foreign-owned firms are more productive, ceteris paribus, as expected. Strikingly, larger firms tend to be less productive, perhaps a sign of incomplete restructuring that prevents firms from exploiting the benefits of scale economies. Whereas innovation would be expected to be associated with higher productivity, the innovation dummy appears as insignificant in all specifications. This may indicate that the innovation activities carried our within firms may be insufficient to have an impact on productivity. This result could indicate a prevalence of defensive as opposed to strategic restructuring by the firms in the sample, where the former is related to short-term cost-cutting measures, while the latter is focused on increasing the longterm efficiency and viability of the firm, by investing in labour training, fixed assets and

\footnotetext{
${ }^{16}$ In some applications using firm level data it is found that extreme observations, or outliers, tend to shape the results, see Verardi and Wagner (2011) for a discussion. In order to see whether this is an issue for our data, we re-estimated columns (1) and (2) using a robust regression estimator which takes account of outliers. We find that this does not alter much the coefficients in the model. The only exceptions are the innovation and competition variables, which are statistically significant when using robust regression. The results are not reported here to save space, but can be obtained from the authors upon request.
} 
Table 3 Productivity regression results: baseline specifications

\begin{tabular}{|c|c|c|c|c|}
\hline \multirow[t]{2}{*}{ Dependent Variable: Log Output } & \multicolumn{2}{|c|}{ OLS } & \multicolumn{2}{|c|}{ IV } \\
\hline & (1) & (2) & (3) & (4) \\
\hline Bribe Tax & $\begin{array}{c}-0.002 \\
(0.005)\end{array}$ & & $\begin{array}{l}-0.051 \\
(0.019) * * *\end{array}$ & \\
\hline Time Tax & & $\begin{array}{c}0.000 \\
(0.000)\end{array}$ & & $\begin{array}{c}-0.001 \\
(0.001)\end{array}$ \\
\hline L & $\begin{array}{l}0.281 \\
(0.039) * * *\end{array}$ & $\begin{array}{l}0.273 \\
(0.041) * * *\end{array}$ & $\begin{array}{l}0.285 \\
(0.043)^{* * *}\end{array}$ & $\begin{array}{l}0.274 \\
(0.042) * * *\end{array}$ \\
\hline M & $\begin{array}{l}0.353 \\
(0.027)^{* * *}\end{array}$ & $\begin{array}{l}0.350 \\
(0.028)^{* * *}\end{array}$ & $\begin{array}{l}0.354 \\
(0.028)^{* * *}\end{array}$ & $\begin{array}{l}0.355 \\
(0.029)^{* * *}\end{array}$ \\
\hline $\mathrm{K}^{\text {Equipment }}$ & $\begin{array}{l}0.062 \\
(0.015)^{* * *}\end{array}$ & $\begin{array}{l}0.068 \\
(0.016)^{* * *}\end{array}$ & $\begin{array}{l}0.063 \\
(0.016)^{* * *}\end{array}$ & $\begin{array}{l}0.069 \\
(0.015) * * *\end{array}$ \\
\hline $\mathrm{K}^{\mathrm{Land}}$ & $\begin{array}{c}0.012 \\
(0.011)\end{array}$ & $\begin{array}{l}0.020 \\
(0.012)^{*}\end{array}$ & $\begin{array}{c}0.008 \\
(0.012)\end{array}$ & $\begin{array}{c}0.015 \\
(0.012)\end{array}$ \\
\hline Exporter & $\begin{array}{l}0.017 \\
(0.004) * * *\end{array}$ & $\begin{array}{l}0.016 \\
(0.004)^{* * *}\end{array}$ & $\begin{array}{l}0.019 \\
(0.004) * * *\end{array}$ & $\begin{array}{l}0.017 \\
(0.004) * * *\end{array}$ \\
\hline Age & $\begin{array}{c}-0.000 \\
(0.000)\end{array}$ & $\begin{array}{c}-0.000 \\
(0.000)\end{array}$ & $\begin{array}{c}-0.000 \\
(0.000)\end{array}$ & $\begin{array}{c}-0.000 \\
(0.000)\end{array}$ \\
\hline SizeM & $\begin{array}{l}-0.036 \\
(0.008) * * *\end{array}$ & $\begin{array}{l}-0.037 \\
(0.008)^{* * *}\end{array}$ & $\begin{array}{l}-0.033 \\
(0.009) * * *\end{array}$ & $\begin{array}{l}-0.038 \\
(0.009) * * *\end{array}$ \\
\hline SizeL & $\begin{array}{l}-0.019 \\
(0.005)^{* * *}\end{array}$ & $\begin{array}{l}-0.019 \\
(0.005)^{* * *}\end{array}$ & $\begin{array}{l}-0.017 \\
(0.005)^{* * *}\end{array}$ & $\begin{array}{l}-0.018 \\
(0.005) * * *\end{array}$ \\
\hline Foreign Owned & $\begin{array}{l}0.012 \\
(0.005)^{* *}\end{array}$ & $\begin{array}{l}0.012 \\
(0.005)^{* *}\end{array}$ & $\begin{array}{l}0.015 \\
(0.005)^{* * *}\end{array}$ & $\begin{array}{l}0.011 \\
(0.005)^{* *}\end{array}$ \\
\hline Innovator & $\begin{array}{c}0.006 \\
(0.004)\end{array}$ & $\begin{array}{c}0.006 \\
(0.004)\end{array}$ & $\begin{array}{c}0.006 \\
(0.004)\end{array}$ & $\begin{array}{c}0.004 \\
(0.004)\end{array}$ \\
\hline Competition & $\begin{array}{c}-0.002 \\
(0.001)\end{array}$ & $\begin{array}{c}-0.001 \\
(0.001)\end{array}$ & $\begin{array}{c}-0.000 \\
(0.001)\end{array}$ & $\begin{array}{c}-0.001 \\
(0.001)\end{array}$ \\
\hline Courts & $\begin{array}{c}-0.003 \\
(0.004)\end{array}$ & $\begin{array}{c}-0.005 \\
(0.004)\end{array}$ & $\begin{array}{c}0.004 \\
(0.005)\end{array}$ & $\begin{array}{c}-0.003 \\
(0.004)\end{array}$ \\
\hline Political Stability & $\begin{array}{c}0.004 \\
(0.004)\end{array}$ & $\begin{array}{c}0.003 \\
(0.004)\end{array}$ & $\begin{array}{l}0.006 \\
(0.004)^{*}\end{array}$ & $\begin{array}{c}0.003 \\
(0.004)\end{array}$ \\
\hline $\begin{array}{l}\text { Constant } \\
\text { Country Dummies } \\
\text { Sector Dummies }\end{array}$ & $\begin{array}{l}\text { YES } \\
\text { YES } \\
\text { YES }\end{array}$ & $\begin{array}{l}\text { YES } \\
\text { YES } \\
\text { YES }\end{array}$ & $\begin{array}{l}\text { YES } \\
\text { YES } \\
\text { YES }\end{array}$ & $\begin{array}{l}\text { YES } \\
\text { YES } \\
\text { YES }\end{array}$ \\
\hline $\begin{array}{l}\text { R squared } \\
\text { Wu-Hausman ( } p \text {-value) } \\
\text { Hansen J ( } p \text {-value) } \\
\text { F-Stat }\end{array}$ & 0.86 & 0.87 & $\begin{array}{r}0.77 \\
0.01 \\
0.59 \\
43.49\end{array}$ & $\begin{array}{r}0.78 \\
0.11 \\
0.45 \\
27.51\end{array}$ \\
\hline Observations & 1666 & 1519 & 1629 & 1490 \\
\hline
\end{tabular}

Note: Standard errors clustered by country-industry in brackets. ${ }^{*}$ significant at $10 \%$; ${ }^{*}$ significant at $5 \%$; *** significant at $1 \%$. Instruments: bribe tax: country-industry bribe tax, dummy for female owner, dummy for electricity connection application. Time tax: country-industry time tax, dummy for female owner. * significant at $10 \%$; ** significant at $5 \% ; * *$ significant at $1 \%$ 
other innovation related activities such as R\&D (Grosfeld/Roland 1997; Frydman et al. 1999). The other controls are statistically insignificant.

Examination of the OLS results in columns 1 and 2 shows that the coefficients on both time and bribe tax are statistically insignificant. It is, however, unlikely that the corruption variables are exogenous in this productivity estimation. For example, highly productive firms may have a better ability to engage in bribing or may be preferred targets of bureaucrats aiming at exacting bribes. This would introduce reverse causality in the equation or, more formally, a correlation between the right-hand-side variable and the error term. Another potential source of endogeneity is the impact of unobserved institutional characteristics at the firm level. We argue that our measures of perception of the quality of courts and political instability go some way to address these concerns.

The Wu-Hausman test is performed to check whether bribe is endogenous and the results are given at the bottom of Table 3. The significant p-value rejects the null hypothesis of exogeneity of bribe tax. This is not the case for time tax, however, where we cannot reject exogeneity. However, in both cases we implement an instrumental variables (IV) technique to estimate equation (1) to check the implications this has for the coefficient on corruption.

The bribe tax has a negative and significant effect on productivity when adjusting for potential endogeneity bias (Table 3, column 3). The negative and significant coefficient of bribe tax indicates that firms that pay bribes to officials experience lower productivity than other firms. The size of the coefficient suggests that a firm that pays bribes is on average around 5 percent less productive than a non-corrupt firm. ${ }^{17}$ While not directly comparable, it is interesting to note that Fisman and Svensson (2005) find that bribes reduce firm growth by around 3 percent. The table also shows that, none of the controls for institutional quality are significantly correlated with firm-level productivity. We also still fail to find a statistically significant impact of time tax on firm level productivity (Column 3).

\subsection{Trade-offs between the bribe tax and the time tax}

The preceding analysis has shown that the payment of bribes is negatively associated with the productivity of the bribing firm, time spent dealing with bureaucratic requirements per se appears to be irrelevant. However, it has been argued that the occurrence of corruption may not be independent of the length of bureaucratic processes. These may, in fact, be deliberately established by state officials with the intent of exacting bribes. In this context, the payment of bribes might help "grease the wheels of commerce" by speeding up bureaucratic requirements, as captured by the time tax, and lead to a second best outcome for the bribing firm. The challenge is, therefore, to examine whether the (negative) effect of bribes on productivity is somehow dependent on the time that firms have to spend dealing with red tape.

A direct way to investigate the trade-offs between bribes and red tape and to test whether such trade-offs are of the "efficient grease" type, is to include the bribe tax and the time tax jointly in the empirical specification, together with their interaction. Examination of the sign, significance and magnitude of the coefficient on the interaction term would allow drawing conclusions on the nature of the relationships between bribe payments

$\overline{{ }^{17} \text { Calculated as }} \exp (-0.051)-1$ 
Table 4 Trade-off between the bribe tax and the time tax

\begin{tabular}{|c|c|c|c|c|}
\hline Dependent Variable: Log Output & $\begin{array}{l}\text { (1) } \\
\text { OLS }\end{array}$ & $\begin{array}{l}\text { (2) } \\
\text { IV }\end{array}$ & $\begin{array}{l}\text { (3) } \\
\text { OLS }\end{array}$ & $\begin{array}{l}\text { (4) } \\
\text { IV }\end{array}$ \\
\hline Bribe tax & $\begin{array}{c}0.001 \\
(0.006)\end{array}$ & $\begin{array}{l}-0.045 \\
(0.020)^{* *}\end{array}$ & $\begin{array}{c}0.001 \\
(0.008)\end{array}$ & $\begin{array}{r}-0.090 \\
(0.071)\end{array}$ \\
\hline Time tax & $\begin{array}{c}0.000 \\
(0.000)\end{array}$ & $\begin{array}{c}-0.001 \\
(0.001)\end{array}$ & $\begin{array}{c}0.000 \\
(0.000)\end{array}$ & $\begin{array}{c}-0.001 \\
(0.001)\end{array}$ \\
\hline Time tax * Bribe tax & & & $\begin{array}{c}0.000 \\
(0.000)\end{array}$ & $\begin{array}{c}0.004 \\
(0.005)\end{array}$ \\
\hline $\mathrm{L}$ & $\begin{array}{l}0.272 \\
(0.041)^{* * *}\end{array}$ & $\begin{array}{l}0.278 \\
(0.045)^{* * *}\end{array}$ & $\begin{array}{l}0.272 \\
(0.041)^{* * *}\end{array}$ & $\begin{array}{l}0.271 \\
(0.044)^{* * *}\end{array}$ \\
\hline M & $\begin{array}{l}0.350 \\
(0.028)^{* * *}\end{array}$ & $\begin{array}{l}0.352 \\
(0.029)^{* * *}\end{array}$ & $\begin{array}{l}0.350 \\
(0.028)^{* * *}\end{array}$ & $\begin{array}{l}0.352 \\
(0.029)^{* * *}\end{array}$ \\
\hline $\mathrm{K}^{\text {Equipment }}$ & $\begin{array}{l}0.068 \\
(0.016) * * *\end{array}$ & $\begin{array}{l}0.071 \\
(0.015)^{* * *}\end{array}$ & $\begin{array}{l}0.068 \\
(0.016)^{* * *}\end{array}$ & $\begin{array}{l}0.076 \\
(0.018)^{* * *}\end{array}$ \\
\hline $\mathrm{K}^{\text {Land }}$ & $\begin{array}{l}0.020 \\
(0.012)^{*}\end{array}$ & $\begin{array}{c}0.014 \\
(0.013)\end{array}$ & $\begin{array}{l}0.020 \\
(0.012)^{*}\end{array}$ & $\begin{array}{c}0.016 \\
(0.014)\end{array}$ \\
\hline Exporter & $\begin{array}{l}0.016 \\
(0.004)^{* * *}\end{array}$ & $\begin{array}{l}0.018 \\
(0.004)^{* * *}\end{array}$ & $\begin{array}{l}0.016 \\
(0.004)^{* * *}\end{array}$ & $\begin{array}{l}0.019 \\
(0.005) * * *\end{array}$ \\
\hline Age & $\begin{array}{r}-0.000 \\
(0.000)\end{array}$ & $\begin{array}{c}-0.000 \\
(0.000)\end{array}$ & $\begin{array}{r}-0.000 \\
(0.000)\end{array}$ & $\begin{array}{c}-0.000 \\
(0.000)\end{array}$ \\
\hline SizeM & $\begin{array}{l}-0.038 \\
(0.008) * * *\end{array}$ & $\begin{array}{l}-0.035 \\
(0.009)^{* * *}\end{array}$ & $\begin{array}{l}-0.038 \\
(0.008)^{* * *}\end{array}$ & $\begin{array}{l}-0.036 \\
(0.010)^{* * *}\end{array}$ \\
\hline SizeL & $\begin{array}{l}-0.019 \\
(0.005)^{* * *}\end{array}$ & $\begin{array}{l}-0.017 \\
(0.005)^{* * *}\end{array}$ & $\begin{array}{l}-0.019 \\
(0.005) * * *\end{array}$ & $\begin{array}{l}-0.017 \\
(0.006) * * *\end{array}$ \\
\hline Foreign Owned & $\begin{array}{l}0.012 \\
(0.005)^{* *}\end{array}$ & $\begin{array}{l}0.014 \\
(0.006)^{* *}\end{array}$ & $\begin{array}{l}0.012 \\
(0.005)^{* *}\end{array}$ & $\begin{array}{c}0.011 \\
(0.007)\end{array}$ \\
\hline Innovator & $\begin{array}{c}0.006 \\
(0.004)\end{array}$ & $\begin{array}{c}0.005 \\
(0.004)\end{array}$ & $\begin{array}{c}0.006 \\
(0.004)\end{array}$ & $\begin{array}{c}0.005 \\
(0.004)\end{array}$ \\
\hline Competition & $\begin{array}{c}-0.001 \\
(0.001)\end{array}$ & $\begin{array}{c}0.000 \\
(0.001)\end{array}$ & $\begin{array}{c}-0.001 \\
(0.001)\end{array}$ & $\begin{array}{c}0.000 \\
(0.001)\end{array}$ \\
\hline Courts & $\begin{array}{c}-0.005 \\
(0.004)\end{array}$ & $\begin{array}{c}0.003 \\
(0.006)\end{array}$ & $\begin{array}{c}-0.005 \\
(0.004)\end{array}$ & $\begin{array}{c}0.001 \\
(0.007)\end{array}$ \\
\hline Political Stability & $\begin{array}{c}0.003 \\
(0.004)\end{array}$ & $\begin{array}{c}0.005 \\
(0.004)\end{array}$ & $\begin{array}{c}0.003 \\
(0.004)\end{array}$ & $\begin{array}{c}0.003 \\
(0.005)\end{array}$ \\
\hline $\begin{array}{l}\text { Constant } \\
\text { Country Dummies } \\
\text { Sector Dummies }\end{array}$ & $\begin{array}{l}\text { YES } \\
\text { YES } \\
\text { YES }\end{array}$ & $\begin{array}{l}\text { YES } \\
\text { YES } \\
\text { YES }\end{array}$ & $\begin{array}{l}\text { YES } \\
\text { YES } \\
\text { YES }\end{array}$ & $\begin{array}{l}\text { YES } \\
\text { YES } \\
\text { YES }\end{array}$ \\
\hline $\begin{array}{l}\text { R squared } \\
\text { Wu-Hausman [p-value] } \\
\text { Hansen J [p-value] } \\
\text { F-Stat [time tax] } \\
\text { F-Stat [bribe tax] } \\
\text { F-Stat [time tax * bribe tax] }\end{array}$ & 0.87 & $\begin{array}{r}0.78 \\
0.03 \\
0.69 \\
11.26 \\
29.48\end{array}$ & 0.87 & $\begin{array}{r}0.77 \\
0.05 \\
0.89 \\
11.26 \\
29.48 \\
6.90\end{array}$ \\
\hline Observations & 1519 & 1490 & 1519 & 1490 \\
\hline
\end{tabular}

Note: Standard errors clustered by country-industry in brackets. ${ }^{*}$ significant at $10 \%$; ${ }^{*}$ significant at $5 \%$; ${ }^{* *}$ significant at $1 \%$.

Note: Instruments used in column (2) are the same as in Table 4. In column (4), we include the interaction of industry level bribe tax and industry level time tax as additional instrument in order to be able to test for overidentification restrictions using the Hansen $J$ test. 
and red tape in our sample and to verify the extent to which the effect of corruption on productivity is conditional on time consuming dealings with bureaucracy.

Table 4 shows that the interaction of time tax and bribe tax is insignificant, failing to provide evidence of a link between inefficient bureaucracy, corruption and productivity. The time tax remains statistically insignificant, whereas the effect of the bribe tax for productivity remains negative but becomes statistically insignificant when including the interaction term. This suggests that the specification with the interaction term does not fit the data well. The coefficient for factor inputs and other control variables remain largely unaltered compared to Table 3 .

\subsection{Does the institutional environment matter?}

An interesting question that can be answered with our data is whether there are any systematic variations in the effects of corruption on productivity across groups of countries. In order to do so, we explicitly consider the potential influence of broader institutional characteristics of the country. For this purpose, two variables, obtained from sources other than the BEEPS, are used. As discussed above, the first is the Corruption Perception Index computed by Transparency International. The second is a measure of the quality of the legal framework taken from the Global Competitiveness Report. As shown in Table A3 in the Appendix, mirroring the large differences in income per capita, these two variables also present substantial variation across the countries in the sample. We, therefore, posit that the effect of bribe and time tax on productivity may depend on the overall prevalence of corruption in the country - in the spirit of theories highlighting the role of social effects on individual behaviour - and on the effectiveness of the legal framework in preventing and sanctioning corrupt behaviour. This hypothesis is tested by estimating model (3) and the results are given in Tables 5 and 6 .

Overall, our results indicate that the relationship between corruption and economic performance is conditional on the overall level of institutional quality. In particular, the coefficients on time tax and its interaction are statistically insignificant, the coefficient of bribe tax is still negative and significant in all specifications, whereas the interactive term, bribe $\times$ institution, is positive and significant for both the CPI and the quality of the legal framework. ${ }^{18}$ For Table 6, the coefficient estimates imply that for the average firm in a country with the average level of CPI, the effect of a bribe is an increase in productivity by roughly 5 percent. For the same firm in a country with a CPI at one standard deviation less than the mean, the effect of bribery is to reduce productivity by 8 percent. ${ }^{19}$

This implies that in highly corrupt environments (i.e. for lower values of the CPI) or in countries with low levels of legal quality, bribes have higher negative impact on productivity, in line with Meon and Sekkat (2005). At the same time, as the value of the CPI or the legal quality indictor increases, the total effect of bribe on productivity becomes less negative and, beyond a certain threshold, could even be positive. This could be because, in an environment that is generally free of corruption, paying a bribe might result in a

${ }^{18}$ As a robustness check, we also estimated the model using labour productivity (output per worker) as dependent variable. In this case, the results for bribe tax and the interaction with CPI hold, however, the coefficients of bribe tax and the interaction with the legal framework indicator are statistically insignificant. Results are available from the authors upon request.

19 The mean level of CPI is 3.393 , the standard deviation is 1.151 , see Table 2 . The first result is calculated as $\exp (-0.345+0.116 * 3.393)-1$; the second as $\exp (-0.345+0.116 * 2.232)$. 
Table 5 Productivity regression results: Country-level corruption

\begin{tabular}{|c|c|c|c|c|}
\hline \multirow[t]{2}{*}{ Dependent Variable: Log Output } & \multicolumn{2}{|c|}{ OLS } & \multicolumn{2}{|c|}{ IV } \\
\hline & (1) & (2) & (3) & (4) \\
\hline Bribe tax & $\begin{array}{c}0.009 \\
(0.016)\end{array}$ & & $\begin{array}{c}-0.345 \\
(0.186)^{*}\end{array}$ & \\
\hline Bribe tax ${ }^{*} \mathrm{CPI}$ & $\begin{array}{c}-0.004 \\
(0.005)\end{array}$ & & $\begin{array}{l}0.116 \\
(0.065)^{*}\end{array}$ & \\
\hline Time tax & & $\begin{array}{c}0.000 \\
(0.000)\end{array}$ & & $\begin{array}{c}0.000 \\
(0.005)\end{array}$ \\
\hline Time tax ${ }^{*} \mathrm{CPI}$ & & $\begin{array}{c}-0.000 \\
(0.000)\end{array}$ & & $\begin{array}{c}-0.000 \\
(0.001)\end{array}$ \\
\hline cpi_2008 & $\begin{array}{l}-0.010 \\
(0.004)^{* *}\end{array}$ & $\begin{array}{l}-0.009 \\
(0.005)^{*}\end{array}$ & $\begin{array}{l}-0.067 \\
(0.029)^{* *}\end{array}$ & $\begin{array}{c}-0.026 \\
(0.025)\end{array}$ \\
\hline L & $\begin{array}{l}0.281 \\
(0.039)^{* * *}\end{array}$ & $\begin{array}{l}0.272 \\
(0.041)^{* * *}\end{array}$ & $\begin{array}{l}0.301 \\
(0.058)^{* * *}\end{array}$ & $\begin{array}{l}0.272 \\
(0.041) * * *\end{array}$ \\
\hline M & $\begin{array}{l}0.353 \\
(0.027)^{* * *}\end{array}$ & $\begin{array}{l}0.350 \\
(0.028)^{* * *}\end{array}$ & $\begin{array}{l}0.367 \\
(0.035)^{* * *}\end{array}$ & $\begin{array}{l}0.352 \\
(0.030)^{* * *}\end{array}$ \\
\hline $\mathrm{K}^{\text {Equipment }}$ & $\begin{array}{l}0.061 \\
(0.015)^{* * *}\end{array}$ & $\begin{array}{l}0.068 \\
(0.016) * * *\end{array}$ & $\begin{array}{l}0.088 \\
(0.025)^{* * *}\end{array}$ & $\begin{array}{l}0.067 \\
(0.015)^{* * *}\end{array}$ \\
\hline $\mathrm{K}^{\text {Land }}$ & $\begin{array}{c}0.013 \\
(0.011)\end{array}$ & $\begin{array}{l}0.020 \\
(0.012)^{*}\end{array}$ & $\begin{array}{c}-0.015 \\
(0.023)\end{array}$ & $\begin{array}{c}0.020 \\
(0.015)\end{array}$ \\
\hline Exporter & $\begin{array}{l}0.017 \\
(0.004)^{* * *}\end{array}$ & $\begin{array}{l}0.016 \\
(0.004) * * *\end{array}$ & $\begin{array}{l}0.023 \\
(0.007)^{* * *}\end{array}$ & $\begin{array}{l}0.016 \\
(0.004) * * *\end{array}$ \\
\hline Age & $\begin{array}{c}-0.000 \\
(0.000)\end{array}$ & $\begin{array}{c}-0.000 \\
(0.000)\end{array}$ & $\begin{array}{c}-0.000 \\
(0.000)\end{array}$ & $\begin{array}{c}-0.000 \\
(0.000)\end{array}$ \\
\hline SizeM & $\begin{array}{l}-0.037 \\
(0.008)^{* * *}\end{array}$ & $\begin{array}{l}-0.037 \\
(0.008)^{* * *}\end{array}$ & $\begin{array}{c}-0.019 \\
(0.013)\end{array}$ & $\begin{array}{l}-0.037 \\
(0.008)^{* * *}\end{array}$ \\
\hline SizeL & $\begin{array}{l}-0.019 \\
(0.005)^{* * *}\end{array}$ & $\begin{array}{l}-0.019 \\
(0.005)^{* * *}\end{array}$ & $\begin{array}{c}-0.008 \\
(0.008)\end{array}$ & $\begin{array}{l}-0.018 \\
(0.005)^{* * *}\end{array}$ \\
\hline Foreign Owned & $\begin{array}{l}0.012 \\
(0.005)^{* *}\end{array}$ & $\begin{array}{l}0.012 \\
(0.005)^{* *}\end{array}$ & $\begin{array}{l}0.020 \\
(0.007)^{* * *}\end{array}$ & $\begin{array}{l}0.011 \\
(0.006)^{* *}\end{array}$ \\
\hline Innovator & $\begin{array}{c}0.006 \\
(0.004)\end{array}$ & $\begin{array}{c}0.006 \\
(0.004)\end{array}$ & $\begin{array}{c}0.004 \\
(0.004)\end{array}$ & $\begin{array}{c}0.005 \\
(0.005)\end{array}$ \\
\hline Competition & $\begin{array}{c}-0.002 \\
(0.001)\end{array}$ & $\begin{array}{c}-0.001 \\
(0.001)\end{array}$ & $\begin{array}{c}-0.001 \\
(0.002)\end{array}$ & $\begin{array}{c}-0.001 \\
(0.001)\end{array}$ \\
\hline Courts & $\begin{array}{c}-0.003 \\
(0.004)\end{array}$ & $\begin{array}{c}-0.005 \\
(0.004)\end{array}$ & $\begin{array}{c}0.008 \\
(0.008)\end{array}$ & $\begin{array}{c}-0.004 \\
(0.004)\end{array}$ \\
\hline Political Stability & $\begin{array}{c}0.005 \\
(0.004)\end{array}$ & $\begin{array}{c}0.003 \\
(0.004)\end{array}$ & $\begin{array}{c}0.005 \\
(0.004)\end{array}$ & $\begin{array}{c}0.003 \\
(0.004)\end{array}$ \\
\hline $\begin{array}{l}\text { Constant } \\
\text { Country Dummies } \\
\text { Sector Dummies }\end{array}$ & $\begin{array}{l}\text { YES } \\
\text { YES } \\
\text { YES }\end{array}$ & $\begin{array}{l}\text { YES } \\
\text { YES } \\
\text { YES }\end{array}$ & $\begin{array}{l}\text { YES } \\
\text { YES } \\
\text { YES }\end{array}$ & $\begin{array}{l}\text { YES } \\
\text { YES } \\
\text { YES }\end{array}$ \\
\hline $\begin{array}{l}\text { R squared } \\
\text { Wu-Hausman [p-value] } \\
\text { Hansen J [p-value] } \\
\text { F-Stat }\end{array}$ & 0.86 & 0.87 & $\begin{array}{l}0.72 \\
0.05 \\
0.54 \\
1.99\end{array}$ & $\begin{array}{l}0.80 \\
0.99 \\
0.93 \\
3.49\end{array}$ \\
\hline Observations & 1666 & 1519 & 1252 & 1490 \\
\hline
\end{tabular}

Note: Standard errors clustered by country-industry in brackets. ${ }^{*}$ significant at $10 \%$; ${ }^{*}$ significant at $5 \%$; ${ }^{* *}$ significant at $1 \%$. Instruments: as in Table 3 , additionally; country-industry time tax; country-industry bribe tax. 
Table 6 Productivity regression results: Quality of the legal framework

\begin{tabular}{|c|c|c|c|c|}
\hline \multirow[t]{2}{*}{ Dependent Variable: Log Output } & \multicolumn{2}{|c|}{ OLS } & \multicolumn{2}{|c|}{ IV } \\
\hline & (1) & (2) & (3) & (4) \\
\hline Bribe tax & $\begin{array}{c}-0.033 \\
(0.035)\end{array}$ & & $\begin{array}{l}-1.506 \\
(0.787)^{*}\end{array}$ & \\
\hline Bribe tax $*$ LF & $\begin{array}{c}0.010 \\
(0.012)\end{array}$ & & $\begin{array}{l}0.503 \\
(0.271)^{*}\end{array}$ & \\
\hline Time tax & & $\begin{array}{c}-0.000 \\
(0.001)\end{array}$ & & $\begin{array}{c}-0.005 \\
(0.015)\end{array}$ \\
\hline Time $\operatorname{tax} *$ LF & & $\begin{array}{c}0.000 \\
(0.000)\end{array}$ & & $\begin{array}{c}0.002 \\
(0.005)\end{array}$ \\
\hline Legal framework & $\begin{array}{l}0.026 \\
(0.008)^{* * *}\end{array}$ & $\begin{array}{l}0.026 \\
(0.009) * * *\end{array}$ & $\begin{array}{r}-0.130 \\
(0.144)\end{array}$ & $\begin{array}{c}-0.092 \\
(0.085)\end{array}$ \\
\hline L & $\begin{array}{l}0.261 \\
(0.042)^{* * *}\end{array}$ & $\begin{array}{l}0.247 \\
(0.043)^{* * *}\end{array}$ & $\begin{array}{l}0.285 \\
(0.054) * * *\end{array}$ & $\begin{array}{l}0.235 \\
(0.053)^{* * *}\end{array}$ \\
\hline M & $\begin{array}{l}0.357 \\
(0.031)^{* * *}\end{array}$ & $\begin{array}{l}0.355 \\
(0.032)^{* * *}\end{array}$ & $\begin{array}{l}0.333 \\
(0.042)^{* * *}\end{array}$ & $\begin{array}{l}0.383 \\
(0.037)^{* * *}\end{array}$ \\
\hline $\mathrm{K}^{\text {Equipment }}$ & $\begin{array}{l}0.063 \\
(0.016)^{* * *}\end{array}$ & $\begin{array}{l}0.071 \\
(0.016)^{* * *}\end{array}$ & $\begin{array}{l}0.080 \\
(0.025)^{* * *}\end{array}$ & $\begin{array}{l}0.070 \\
(0.020)^{* * *}\end{array}$ \\
\hline $\mathrm{K}^{\text {Land }}$ & $\begin{array}{c}0.007 \\
(0.013)\end{array}$ & $\begin{array}{c}0.016 \\
(0.013)\end{array}$ & $\begin{array}{c}0.009 \\
(0.016)\end{array}$ & $\begin{array}{c}0.013 \\
(0.015)\end{array}$ \\
\hline Exporter & $\begin{array}{l}0.018 \\
(0.004) * * *\end{array}$ & $\begin{array}{l}0.017 \\
(0.004)^{* * *}\end{array}$ & $\begin{array}{c}0.011 \\
(0.007)^{*}\end{array}$ & $\begin{array}{l}0.018 \\
(0.006) * * *\end{array}$ \\
\hline Age & $\begin{array}{c}-0.000 \\
(0.000)\end{array}$ & $\begin{array}{r}-0.000 \\
(0.000)\end{array}$ & $\begin{array}{c}0.000 \\
(0.000)\end{array}$ & $\begin{array}{c}-0.000 \\
(0.000)\end{array}$ \\
\hline SizeM & $\begin{array}{l}-0.040 \\
(0.008) * * *\end{array}$ & $\begin{array}{l}-0.042 \\
(0.008) * * *\end{array}$ & $\begin{array}{l}-0.032 \\
(0.011)^{* * *}\end{array}$ & $\begin{array}{l}-0.035 \\
(0.012) * * *\end{array}$ \\
\hline SizeL & $\begin{array}{l}-0.020 \\
(0.005)^{* * *}\end{array}$ & $\begin{array}{l}-0.021 \\
(0.005) * * *\end{array}$ & $\begin{array}{l}-0.017 \\
(0.007)^{* *}\end{array}$ & $\begin{array}{l}-0.016 \\
(0.007)^{* *}\end{array}$ \\
\hline Foreign Owned & $\begin{array}{l}0.014 \\
(0.005)^{* * *}\end{array}$ & $\begin{array}{l}0.014 \\
(0.005)^{* * *}\end{array}$ & $\begin{array}{l}0.027 \\
(0.010)^{* * *}\end{array}$ & $\begin{array}{l}0.022 \\
(0.006)^{* * *}\end{array}$ \\
\hline Innovator & $\begin{array}{c}0.006 \\
(0.004)\end{array}$ & $\begin{array}{c}0.006 \\
(0.004)\end{array}$ & $\begin{array}{c}0.007 \\
(0.005)\end{array}$ & $\begin{array}{c}0.006 \\
(0.005)\end{array}$ \\
\hline Competition & $\begin{array}{c}-0.002 \\
(0.001)^{*}\end{array}$ & $\begin{array}{c}-0.002 \\
(0.001)\end{array}$ & $\begin{array}{r}-0.000 \\
(0.002)\end{array}$ & $\begin{array}{l}-0.002 \\
(0.001)^{*}\end{array}$ \\
\hline Courts & $\begin{array}{c}-0.001 \\
(0.004)\end{array}$ & $\begin{array}{c}-0.003 \\
(0.004)\end{array}$ & $\begin{array}{c}0.004 \\
(0.007)\end{array}$ & $\begin{array}{c}0.000 \\
(0.005)\end{array}$ \\
\hline Political Stability & $\begin{array}{c}0.005 \\
(0.004)\end{array}$ & $\begin{array}{c}0.003 \\
(0.004)\end{array}$ & $\begin{array}{c}0.008 \\
(0.005)\end{array}$ & $\begin{array}{c}0.003 \\
(0.005)\end{array}$ \\
\hline $\begin{array}{l}\text { Constant } \\
\text { Country Dummies } \\
\text { Sector Dummies }\end{array}$ & $\begin{array}{l}\text { YES } \\
\text { YES } \\
\text { YES }\end{array}$ & $\begin{array}{l}\text { YES } \\
\text { YES } \\
\text { YES }\end{array}$ & $\begin{array}{l}\text { YES } \\
\text { YES } \\
\text { YES }\end{array}$ & $\begin{array}{l}\text { YES } \\
\text { YES } \\
\text { YES }\end{array}$ \\
\hline $\begin{array}{l}\text { R squared } \\
\text { Wu-Hausman [p-value] } \\
\text { Hansen J [p-value] } \\
\text { F-Stat }\end{array}$ & 0.87 & 0.87 & $\begin{array}{l}0.55 \\
0.00 \\
0.85 \\
2.52\end{array}$ & $\begin{array}{l}0.80 \\
0.72 \\
0.68 \\
2.75\end{array}$ \\
\hline Observations & 1504 & 1363 & 1470 & 981 \\
\hline
\end{tabular}

Note: Standard errors clustered by country-industry in brackets. ${ }^{*}$ significant at $10 \%$; ${ }^{*}$ significant at $5 \%$; ${ }^{* *}$ significant at $1 \%$. Instruments: as in Table 3 , additionally country-industry time tax; country-industry bribe tax. 
competitive advantage, perhaps reflected in a marginal gain in firm level productivity. On the other hand, in a highly corrupt environment, social effects of the type modelled by Tirole (1996) may induce most market players to pay a bribe. Hence there would be no competitive edge or gain in productivity to be obtained by paying a bribe. Quite the opposite, paying more bribes allocates resources away from their most productive use, reducing productivity of the firm. Hence productivity gains are more likely to incur to the firms that do not bear the cost of bribes.

\section{Concluding remarks}

Corruption is often identified as one of the primary causes for the underdevelopment of many economies. Nevertheless, some see corruption as a necessary evil that, by "greasing the wheels of commerce", mitigates the negative effects of inefficient bureaucracy, which may be seen as imposing a "time tax" on individuals and firms. At the same time, both the incentives for - and the impact of - corruption may be different across countries, depending on the nature of the surrounding environment, namely on the diffusion of corruption and on the ability of the legal system to sanction corrupt behaviour.

Based on these premises, this study investigates the effect of corruption - interpreted as a "bribe tax" - on firm-level productivity across a diverse sample of countries in Central and Eastern Europe and the Former Soviet Union. The findings of econometric analysis corroborate the hypothesis that corruption has, on balance, negative consequences for enterprise performance. However, the relationship between corruption and economic performance presents some nuances.

First, a comparison of the effects of the bribe tax and the time tax indicates that only bribery negatively affects firm productivity, while lengthy bureaucratic requirements per se have no significant consequences.

Second, an explicit test of the hypothesis that bribes help to mitigate the negative effects of time consuming dealings with bureaucracy does not find confirmation in our data. Contrary to previous studies addressing the same question at the country level, our conclusion is based on a precise definition of the institutional inefficiencies that corruption is supposed to "grease" -namely lengthy bureaucratic requirements - rather than generic measures of "governance".

Third, broader environmental circumstances turn out to play a significant role in determining the impact of firm level corruption on productivity. Results indicate that in highly corrupt environments and where the legal framework is weaker, firms that do not pay bribes are more productive. Furthermore, as the level of institutional quality decreases, the total effect of corruption is increasingly negative. This suggests that, whereas environmental circumstances are beyond the choice set of individual firms, managers retain some degree of autonomy in deciding whether to recur to bribery or not and this affects enterprise performance. 


\section{Appendix}

Table A1 Variable definitions

\begin{tabular}{|c|c|}
\hline Variable & Definition \\
\hline TFP & Total factor productivity, calculated as residual from a production function \\
\hline Y & This establishment's total annual sales \\
\hline K & This establishment spend on purchases of machinery, land and building \\
\hline $\mathrm{L}$ & $\begin{array}{l}\text { Total annual cost of labour (including wages, salaries, bonuses, social secu- } \\
\text { rity payments) }\end{array}$ \\
\hline M & $\begin{array}{l}\text { Total annual cost of raw materials and intermediate goods used in produc- } \\
\text { tion }\end{array}$ \\
\hline Time Tax & $\begin{array}{l}\text { Percentage of time spent by senior management with public officials in } \\
\text { order to obtain favourable interpretation of regulations }\end{array}$ \\
\hline Bribe Tax & $\begin{array}{l}\text { Dummy }=1 \text { if firm replies frequently, usually or always to the question "it } \\
\text { is common to have to pay some irregular additional payment or gifts to get } \\
\text { things done". }\end{array}$ \\
\hline Courts & $\begin{array}{l}\text { Dummy }=1 \text { if firm replies that courts are a major obstacle or very severe } \\
\text { obstacle to the operations of the firm }\end{array}$ \\
\hline Political stability & $\begin{array}{l}\text { Dummy }=1 \text { if firm replies that political instability is a major obstacle or very } \\
\text { severe obstacle to the operations of the firm }\end{array}$ \\
\hline $\mathrm{CPI}$ & $\begin{array}{l}\text { Corruption Perception Index at the country level. It relates to perceptions of } \\
\text { the degree of corruption as seen by business people and country analysts, } \\
\text { and ranges between } 10 \text { (highly clean) and } 0 \text { (highly corrupt). }\end{array}$ \\
\hline Legal Framework & $\begin{array}{l}\text { Indicator from the Global Competitiveness Report at the country level. It } \\
\text { provides a measure of the efficiency of the legal framework in settling dis- } \\
\text { putes ( } 1 \text { = extremely inefficient; } 7=\text { highly efficient). }\end{array}$ \\
\hline Exporter & Dummy $=1$ if firm has positive exports \\
\hline Foreign_Owned & Dummy = 1 if firm has foreign ownership \\
\hline Innovator & Dummy $=1$ if firm has positive expenditure on $R \& D$ \\
\hline Age & Age of firm (years) \\
\hline Sizes & Dummy = 1 for small firm (less than 20 employees) \\
\hline SizeM & Dummy = 1 for medium firm (between 20 and 99 employees) \\
\hline SizeL & Dummy = 1 for large firm (larger than 99 employees) \\
\hline Competition & $\begin{array}{l}\text { Difference between firm's perception and country level average on question } \\
\text { "competition is an obstacle for operations of the establishment" (ranked } \\
\text { between } 0 \text { and } 4 \text { ) }\end{array}$ \\
\hline
\end{tabular}


Table A2 Descriptive statistics of variables used

\begin{tabular}{lcrr}
\hline Variable & Obs & Mean & Std. Dev. \\
\hline TFP & 1666 & 0.22 & 0.90 \\
Time tax & 1519 & 12.81 & 14.79 \\
Bribe Tax & 1666 & 0.11 & 0.31 \\
Courts & 1666 & 0.19 & 0.39 \\
Political stability & 1666 & 0.32 & 0.46 \\
CPI & 1666 & 3.57 & 1.29 \\
Legal Framework & 1504 & 2.98 & 0.51 \\
Exporter & 1666 & 0.49 & 0.50 \\
Foreign_Owned & 1666 & 0.11 & 0.30 \\
Innovator & 1666 & 0.21 & 0.41 \\
Age & 1666 & 20.34 & 20.33 \\
SizeM & 1666 & 0.29 & 0.45 \\
SizeL & 1666 & 0.37 & 0.48 \\
Competition & 1666 & 0.04 & 1.37 \\
\hline
\end{tabular}

Table A3 Descriptive statistics of variables used by country

\begin{tabular}{|c|c|c|c|c|c|c|c|c|c|c|}
\hline & \multicolumn{2}{|c|}{ TFP } & \multicolumn{2}{|c|}{ Bribe Tax } & \multicolumn{2}{|c|}{ Time Tax } & \multicolumn{2}{|r|}{ CPI } & \multicolumn{2}{|c|}{$\begin{array}{c}\text { Legal } \\
\text { Framework }\end{array}$} \\
\hline & Mean & Std. Dev. & Mean & Std. Dev. & Mean & Std. Dev. & Mean & Std. Dev. & Mean & Std. Dev. \\
\hline Albania & 0.85 & 0.95 & 0.03 & 0.17 & 20.38 & 22.56 & 3.40 & 0.00 & 3.60 & 0.00 \\
\hline Belarus & 0.12 & 0.83 & 0.09 & 0.29 & 19.00 & 20.20 & 2.00 & 0.00 & & \\
\hline Georgia & 0.22 & 0.89 & 0.03 & 0.18 & 2.00 & 6.84 & 3.90 & 0.00 & 3.20 & 0.00 \\
\hline Tajikistan & 0.36 & 0.87 & 0.13 & 0.33 & 14.98 & 19.19 & 2.00 & 0.00 & 3.40 & 0.00 \\
\hline Ukraine & 0.25 & 1.11 & 0.21 & 0.41 & 15.01 & 21.93 & 2.50 & 0.00 & 2.30 & 0.00 \\
\hline Uzbekistan & 0.42 & 1.04 & 0.36 & 0.48 & 12.77 & 13.84 & 1.80 & 0.00 & & \\
\hline Russia & 0.02 & 0.83 & 0.23 & 0.42 & 20.17 & 25.66 & 2.10 & 0.00 & 2.90 & 0.00 \\
\hline Poland & -0.01 & 0.84 & 0.04 & 0.21 & 14.14 & 13.77 & 4.60 & 0.00 & 2.80 & 0.00 \\
\hline Romania & 0.19 & 0.92 & 0.18 & 0.38 & 13.50 & 17.95 & 3.80 & 0.00 & 2.90 & 0.00 \\
\hline Serbia & -0.06 & 0.92 & 0.10 & 0.30 & 17.24 & 18.62 & 3.40 & 0.00 & 2.60 & 0.00 \\
\hline Kazakhstan & 0.08 & 0.79 & 0.20 & 0.40 & 6.11 & 11.12 & 2.20 & 0.00 & 3.40 & 0.00 \\
\hline Moldova & 0.47 & 0.96 & 0.09 & 0.29 & 10.49 & 17.24 & 2.90 & 0.00 & & \\
\hline Bosnia & -0.21 & 0.69 & 0.09 & 0.29 & 14.02 & 17.63 & 3.20 & 0.00 & 1.80 & 0.00 \\
\hline Azerbaijan & 0.03 & 0.64 & 0.21 & 0.41 & 2.66 & 4.95 & 1.90 & 0.00 & 3.80 & 0.00 \\
\hline FYROM & 0.20 & 0.65 & 0.08 & 0.27 & 14.80 & 15.36 & 3.60 & 0.00 & 3.20 & 0.00 \\
\hline Armenia & 0.38 & 0.97 & 0.08 & 0.27 & 13.95 & 16.90 & 2.90 & 0.00 & 2.80 & 0.00 \\
\hline Kyrgyz & 0.86 & 1.46 & 0.19 & 0.40 & 4.03 & 8.03 & 1.80 & 0.00 & 2.60 & 0.00 \\
\hline Estonia & 0.02 & 0.87 & 0.02 & 0.15 & 8.32 & 10.74 & 6.60 & 0.00 & 4.20 & 0.00 \\
\hline Czech Rep & 0.85 & 1.77 & 0.03 & 0.18 & 13.46 & 14.67 & 5.20 & 0.00 & 3.40 & 0.00 \\
\hline Hungary & 0.28 & 0.91 & 0.03 & 0.18 & 18.64 & 18.71 & 5.10 & 0.00 & 3.10 & 0.00 \\
\hline Latvia & -0.10 & 0.70 & 0.02 & 0.15 & 8.74 & 12.88 & 5.00 & 0.00 & 3.10 & 0.00 \\
\hline Lithuania & 0.05 & 0.65 & 0.00 & 0.00 & 10.37 & 12.16 & 4.60 & 0.00 & 3.50 & 0.00 \\
\hline Slovakia & -0.04 & 0.74 & 0.07 & 0.26 & 7.38 & 12.44 & 5.00 & 0.00 & 3.00 & 0.00 \\
\hline Slovenia & -0.25 & 0.74 & 0.01 & 0.10 & 9.21 & 9.26 & 6.70 & 0.00 & 4.00 & 0.00 \\
\hline Bulgaria & 0.20 & 0.61 & 0.01 & 0.07 & 17.23 & 15.20 & 3.60 & 0.00 & 2.80 & 0.00 \\
\hline Croatia & -0.19 & 0.73 & 0.00 & 0.06 & 13.17 & 15.67 & 4.40 & 0.00 & 2.60 & 0.00 \\
\hline Montenegro & 0.28 & 1.12 & 0.03 & 0.16 & 9.85 & 11.33 & 3.40 & 0.00 & 3.90 & 0.00 \\
\hline
\end{tabular}




\section{References}

Acemoglu, D. (2006), A Simple Model of Inefficient Institutions. Scandinavian Journal of Economics 108(4): 515-546.

Acemoglu, D., S. Johnson (2005), Unbundling Institutions. Journal of Political Economy 113(5): 949-995.

Acemoglu, D., J.A. Robinson, S. Johnson (2001), The Colonial Origins of Comparative Development: An Empirical Investigation. American Economic Review. December, 91: 1369-1401.

Acemoglu, D., Th. Verdier (1998), Property Rights, Corruption and the Allocation of Talent: A General Equilibrium Approach. The Economic Journal 108: 1381-1403.

Ades, A., R. Di Tella (1999), Rents, Competition, and Corruption. American Economic Review 89(4): 982-993.

Aidt, T.S., J. Dutta (2008), Policy Compromises: Corruption and Regulation in a Democracy. Economics and Politics 20(3): 335-360.

Alesina, A., S. Ardagna, G. Nicoletti, F. Schiantarelli (2005), Regulation and investment. Journal of the European Economic Association 3(4): 791-825.

Aw, B.Y., M.J. Roberts, D.Y. Xu (2008), R\&D Investments, Exporting and the Evolution of Firm Productivity. American Economic Review 98(2): 451-456.

Banerjee, A.V. (1997), A Theory of Misgovernance. Quarterly Journal of Economics 112(4): 1289-1332.

Bardhan, P. (1997), Corruption and Development: A Review of Issues. Journal of Economic Literature 35(3): 1320-1346.

Barsky, R.B., F.Th. Juster, M.S. Kimball, M.D. Shapiro (1997), Preference Parameters and Behavioral Heterogeneity: An Experimental Approach in the Health and Retirement Study. Quarterly Journal of Economics 112(2): 537-579.

Baumol, W.J. (1990), Entrepreneurship: Productive, Unproductive, and Destructive. The Journal of Political Economy 98(5): 893-921.

Blagojevic, S., J.P. Damijan (2013), The impact of corruption and ownership on the performance of firms in Central and Eastern Europe. Post-Communist Economies 25(2): 133-158.

Brunetti, A., B. Weder (2003), A Free Press is Bad News for Corruption. Journal of Public Economics 87(7-8): 1801-1824.

De Rosa, D., N. Gooroochurn, H. Görg (2010), Corruption and Productivity: Firm-level Evidence from the BEEPS Survey World Bank Policy Research Working Paper 5348.

Djankov, S., R. La Porta, F. Lopez-De-Silanes, A. Shleifer (2002), The Regulation of Entry. Quarterly Journal of Economics 117(1): 1-37.

Egger, P.H., H. Winner (2005), Evidence on Corruption as an Incentive for Foreign Direct Investment. European Journal of Political Economy 21: 932-52.

Fisman, R., J. Svensson (2007), Are corruption and taxation really harmful to growth? Firm level evidence. Journal of Development Economics 83(1): 63-75.

Fries, St., T. Lysenko, S. Polenac (2003), The 2002 Business Environment and Enterprise Performance Survey: Results from a survey of 6,100 firms. EBRD, London.

Frydman, R., Ch. Gray, M. Hessel, A. Rapacyinski (1999), When Does Privatisation work? The Impact of Private Ownership on Corporate Performance in the Transition Economies. Quarterly Journal of Economics 114(4): 1153-1191.

Girma, S., H. Görg (2007), Multinationals' Productivity Advantage: Scale or Technology? Economic Inquiry 45(2): 350-362.

Glaeser, E.L., R. La Porta, F. Lopez-de-Silanes, A. Shleifer (2004), Do Institutions Cause Growth? Journal of Economic Growth 9(3): 271-303.

Grosfeld, I., G. Roland (1997), Defensive and Strategic Restructuring in Central European Enterprises. Journal of Transforming Economies and Societies 3: 83-116.

Hellman, J.S., G. Jones, D. Kaufmann (2003), Seize the State, Seize the Day: State Capture, Corruption and Influence in Transition. Journal of Comparative Economics 31(4): 751-773.

Johnson, S., J. McMillan, Ch. Woodruff (2002), Property Rights and Finance. American Economic Review 92(5): 1335-1356. 
Kaufmann, D., S.-J. Wei (1999), Does grease money speed up the wheels of commerce? NBER Working Paper No. 7093.

Klette, T.J., S. Kortum (2004), Innovating Firms and Aggregate Innovation. Journal of Political Economy 112(5): 986-1018.

Krusell, P., J.-V. Rios-Rull (1996), Vested interests in a positive theory of stagnation and growth. Review of Economic Studies 63: 301-329.

Lambsdorff, J. Graf (2003), How corruption affects productivity. Kyklos 56: 457-474.

La Porta, R., F. Lopez-de-Silanes, A. Shleifer, R.W. Vishny (1998), Law and Finance. Journal of Political Economy 106: 1113-1155.

La Porta, R., F. Lopez-de-Silanes, A. Shleifer, R.W. Vishny (1999), The Quality of Government. Journal of Law, Economics and Organization 15(1): 222-279.

Levinsohn, J., A. Petrin (2003), .Estimating production functions using inputs to control for observables.. Review of Economic Studies 70: 317-341.

Lui, F. (1985), An Equilibrium Queuing Model of Bribery. Journal of Political Economy 93(4): 760-781.

Méndez, F., F. Sepúlveda (2006), Corruption, Growth and Political Regimes: Cross-country Evidence. European Journal of Political Economy 22(1): 82-98.

Méon, P.-G., K. Sekkat (2005), Does Corruption Grease or Sand the Wheels of Growth? Public Choice 122: 69-97.

Méon, P.-G., L. Weill (2010), Is Corruption an Efficient Grease? World Development 38(3): 244-259.

Murphy, K., A. Shleifer, R.W. Vishny (1991), The Allocation of Talent: Implications for Growth. Quarterly Journal of Economics 106: 503-530.

Murphy, K., A. Shleifer, R.W. Vishny (1993), Why is Rent-seeking so Costly to Growth? American Economic Review 83(2): 409-414.

North, D.C. (1990), Institutions, Institutional Change and Economic Performance. Cambridge University Press, Cambridge.

Olken, B.A. (2009), Corruption perceptions vs. corruption reality. Journal of Public Economics 93(7-8): 950-964.

Shleifer, A., RW. Vishny (1998), The Grabbing Hand: Government Pathologies and Their Cures. Harvard University Press, Cambridge, MA.

Svensson, J. (2003), Who Must Pay Bribes and How Much? Quarterly Journal of Economics 118(1): 207-230.

Svensson, J. (2005), Eight Questions about Corruption. Journal of Economic Perspectives 19(3): $3-28$.

Swamy, A., St. Knack, Y. Lee, O. Azfar (2001), Gender and corruption. Journal of Development Economics 64: 25-55.

Tirole, J. (1996), A Theory of Collective Reputations (with Applications to the Persistence of Corruption and to Firm Quality). The Review of Economic Studies 63(1): 1-22.

Verardi, V., J. Wagner (2011), Robust Estimation of Linear Fixed Effects Panel Data Models with an Application to the Exporter Productivity Premium. Jahrbücher für Nationalökonomie und Statistik 231: 546-557.

Wagner, J. (2007), Exports and Productivity: A Survey of the Evidence from Firm Level Data. The World Economy 30(1): 60-82.

Donato De Rosa, Ph.D., Financial and Private Sector Development, Vice Presidency, The World Bank, Washington D.C., USA.

dderosa@worldbank.org

Nishaal Gooroochurn, Ph.D., London Metropolitan University, London, UK. nishaal@hotmail.com

Prof. Holger Görg, Ph.D., Institut für Weltwirtschaft, Kiellinie 66, 24105 Kiel, Germany. holger.goerg@ifw-kiel.de 